Diabetologia 10, 155-162 (1974)

(C) by Springer-Verlag 1974

\title{
Abnormalities in Lipogenesis and Triglyceride Secretion by Perfused Livers of Obese-Hyperglycaemic (ob/ob) Mice: Relationship with Hyperinsulinaemia
}

\author{
F. Assimacopoulos-Jeannet, A. Singh, Y. Le Marchand, E. G. Loten and B. Jeanrenaud \\ Laboratoires de Recherches Médicales, Institut d'Histologie et d'Embryologie, Division de Diabétologie et de Biochimie \\ clinique, Département de Médecine, Geneva University Medical School, Geneva, Switzerland
}

Received: August 3, 1973, and in revised form: December 27, 1973

\begin{abstract}
Summary. Carbohydrate and lipid metabolism has been studied in perfused livers of lean and obese-hyperglycaemic $(o b / o b)$ mice. The capacity for gluconeogenesis from lactate or pyruvate was similar in livers of both groups of mice. Incorporation of carbon from labelled pyruvate into hepatic lipids was much higher in livers of $o b / o b$ mice than in those of lean controls. Total lipogenesis, as well as newly synthesized triglyceride secretion by perfused livers, was also estimated, by measuring ${ }^{3} \mathrm{H}$ (from ${ }^{3} \mathrm{H}_{2} \mathrm{O}$ ) incorporation into total (i.e. liver + perfusate) and perfusate triglyceride fatty acids. Lipogenesis, both in the absence or in the presence of substrates, was greater in livers of $o b / o b$ mice than in those of lean controls, as was newly synthesized triglyceride secretion. In the absence of oleate in the perfusate, the secretion of unlabelled triglyceride by livers of $o b / o b$ mice was much higher than that of non-obese mice, but it did not increase
\end{abstract}

further upon addition of oleate, as it did in livers of lean controls. Ketone body production by livers of $a b / o b$ mice, perfused with albumin bound oleate, was considerably lower than that observed in control livers. When $o b / o b$ mice were made relatively insulin deficient by streptozotocin treatment, all these anomalies of lipid metabolism were restored towards normal. It is proposed that hyperinsulinaemia is responsible, at least in part, for the ab. normalities in lipogenesis, triglyceride secretion and fatty acid oxidation to ketone bodies observed in livers of the obese-hyperglycaemic mice.

Key words: Obese-hyperglycaemic mice, hyperinsulinaemia, perfused liver, lipid metabolism, carbohydrate metabolism, lipogenesis, triglyceride secretion, ketogenesis, streptozotocin, gluconeogenesis, lipid disorders.
The Bar Harbor obese mice (C57 BL/6J ob/ob) are characterized by hyperglycaemia, hyperinsulinaemia and obesity. They are thus an interesting experimental model, since they bear some resemblance to human maturity onset diabetes. It has been previously reported that lipogenesis in both liver and adipose tissue in vivo $[1-3]$ or in vitro $[4,5]$ is greater in the obese animals than in lean controls. In the liver of $o b / o b$ mice, the increase in lipogenesis is paralleled by an augmentation in the activity of several lipogenic enzymes, such as acetyl CoA carboxylase [6], fatty acid synthetase [6] and citrate lyase [7], and by an increase in hepatic triglyceride content [4].

One of the difficulties encountered in previous investigations has been the lack of a satisfactory method for the in vitro study of liver metabolism. We have recently developed a method enabling the in situ perfusion of livers of small rodents, such as the mouse [8]. Using this technique, we have studied carbohydrate metabolism and, more specifically, lipogenesis and triglyceride secretion by the perfused liver of lean and $o b / o b$ mice. We have also attempted to assess the role of hyperinsulinaemia in the disorders of lipid metabolism observed in livers of $o b / o b$ mice.

* This work has been supported by the Grant No 3.552.71 and No 3.8080.72 of the Fonds National Suisse de la Recherche Scientifique, Berne, Switzerland, and by a Grant-in-aid of Nestlé-Alimentana, Vevey, Switzerland.

\section{Materials and Methods}

\section{Animals}

Male obese (C57 BL/6J ob/ob) mice purchased from Jackson Memorial Laboratories, Bar Harbor, Maine, and lean controls (C57 BL/6J), mice bred in these Laboratories were used throughout these studies. They were fed ad libitum with laboratory chow, maintained in a constant temperature $\left(23^{\circ} \mathrm{C}\right)$ animal room, with a fixed $(12 \mathrm{~h})$ artificial light cycle, and used at 8-11 weeks of age. Despite these precautions, variations in some metabolic indices (particularly in lipogenesis) have been encountered from one month to another. Absolute values are therefore sometimes less meaning. ful than relative ones. Mice made insulin-deficient were injected intraperitoneally, following a fast of $24 \mathrm{~h}$, with 220 or $230 \mathrm{mg} / \mathrm{kg}$ streptozotocin (The Upjohn Company, Kalamazoo, Michigan), diluted in $0.9 \%$ $\mathrm{NaCl}$, acidified ( $\mathrm{pH} 4$ ) with $0.05 \mathrm{M}$ citric acid.

\section{Perfusion Technique and Medium}

Mice were anaesthetised by intraperitoneal injection of Nembutal $(110 \mathrm{mg} / \mathrm{kg})$ and livers were perfused in situ, according to the method described previously [8]. In most experiments, livers were perfused with recirculating Krebs-Ringer bicarbonate buffer, containing $1.5 \%$ bovine serum albumin (Boehringer Mannheim GmbH, Mannheim, Germany), defatted with charcoal according to Chen [9], 25\% charcoal-treated bovine 
serum [10], 20\% washed bovine erythrocytes [8], and ${ }^{3} \mathrm{H}_{2} \mathrm{O}(8 \mathrm{mCi}$ in $50 \mathrm{ml}$ perfusate), as indicated for each individual experiment. The addition of serum to the perfusate was found to be an absolute requirement for triglyceride secretion. The reason for this is unknown, but may be related to the presence of an apoprotein in the serum, as well as to some other factor(s). Bovine serum was used since it would have been impractical to obtain the quantities of mouse serum required. It is not known whether mouse serum would have allowed a greater triglyceride output. In experiments carried. out with labelled pyruvate (U- ${ }^{14} \mathrm{C}$ pyruvate, $2.5 \mu \mathrm{Ci}$ in $50 \mathrm{ml}$ perfusate), the perfusion medium was not recirculated ("flow through experiment") and was modified to consist of Krebs-Ringer bicarbonate buffer, with $3.5 \%$ defatted albumin, $20 \%$ washed bovine erythrocytes, but no serum.

\section{Analysis of Perfusate and Tissues}

Aliquots $(3 \mathrm{ml})$ of perfusion medium were taken at 30 min intervals. $0.5 \mathrm{ml}$ was deproteinized in $0.5 \mathrm{ml}$ $1 \mathrm{~N}$ perchloric acid and used for the determination of lactate [11], pyruvate [12], acetoacetate [13] and $\beta$ hydroxybutyrate [14]. The nondeproteinized medium was centrifuged at $4^{\circ} \mathrm{C}$ and the supernatant was used to measure glucose with the glucose oxidase method (Biochemica test combination kit, Boehringer, Mannheim GmbH, Germany), free fatty acids by the method of Ho [15], as modified by Heindel et al. [16], and triglycerides $[10] .{ }^{14} \mathrm{C}$ glucose appearance in the perfusate was measured following a previously described method [8], with aliquots $(0.5 \mathrm{ml})$ that had been deproteinized with $0.15 \mathrm{M} \mathrm{Ba}(\mathrm{OH})_{2}$ and $5 \% \mathrm{ZnSO}_{4}$. The production of ${ }^{14} \mathrm{CO}_{2}$ by perfused livers was measured by collecting the perfusate, over a period of $2 \mathrm{~min}$, in a closed tube fitted with a hanging plastic cup, containing a small piece of filter paper moistened with $1 \mathrm{~N} \mathrm{NaOH}$. Following the collection period, $2 \mathrm{ml}$ of $1 \mathrm{~N} \mathrm{H}_{2} \mathrm{SO}_{4}$ was added to the perfusate and $1 \mathrm{~h}$ later the filter paper was removed, dried and counted in toluene scintillation fluid. Blanks were done with perfusate which had not been circulated through a liver. At the end of the experiment with recirculating medium, the remaining medium was collected and centrifuged. A $4 \mathrm{ml}$ sample was extracted according to the procedure of Folch et al. [17], and washed 4 times. Following removal of the upper phase, the chloroform phase was dried and saponified for $60 \mathrm{~min}$ at $75^{\circ}$ with $3 \mathrm{ml} 0.5 \mathrm{~N}$, alcoholic KOH. The alkaline solution was then acidified with $25 \% \quad \mathrm{H}_{2} \mathrm{SO}_{4}$ and fatty acids extracted 3 times with petroleum ether. Petroleum ether extracts were evaporated, the fatty acids redissolved in toluene scintillation fluid and their radioactive content determined in a liquid scintillation Spectrometer (Packard Instrument, Inc., Tri-Carb Model 3380, Downers Grove, Illinois). The non-saponified fraction found in the perfusate was negligible and its extraction therefore omitted. Pieces of liver $(300-400 \mathrm{mg})$ were homogenized by sonication (Sonifier B-12, Branson Sonic
Power Company, Connecticut) in methanol and their lipids extracted and washed 3 times according to Folch et al. [17]. The chloroform phase was dried and saponified for $90 \mathrm{~min}$ at $75^{\circ}$ in $3 \mathrm{ml} 0.5 \mathrm{~N}$ alcoholic $\mathrm{KOH}$. The non-saponifiable fraction was extracted 3 times with petroleum ether, the infranatant acidified, and fatty acids extracted into petroleum ether as described above. Aliquots of the saponifiable fraction were evaporated and counted for their radioactive content. Liver lipids were determined by weighing aliquots of the washed chloroform extract after evaporation.

\section{Electron Microscopy}

The thin sections were prepared in a manner described previously [10] and were examined with a Philips EM 300 or Zeiss EM 9 microscope.

\section{Calculations}

All results have been expressed per gramme of wet liver weight. Tritium incorporation into lipids was calculated on the basis of $\mathrm{H}^{+}$specific activity in the initial medium (53 M water concentration) and results given as patom $\mathrm{H}^{+}$per gramme wet liver weight. ${ }^{3} \mathrm{H}_{2} \mathrm{O}$ specific activity did not change during the $2 \mathrm{~h}$ perfusion time.

\section{Chemicals}

All organic and inorganic chemicals were purchased from E. Merck (Darmstadt, Germany) or Fluka AG (Buchs, Switzerland) and were of analytical grade. Labelled compounds came from the Radiochemical Centre (Amersham, Buckinghamshire, England). Most enzymes and coenzymes were a gift of Dr. Schmidt (Boehringer Mannheim GmbH, Mannheim, Germany). Zeolite was obtained from Serva (Entwicklungslabor, Heidelberg, Germany).

\section{Results}

Gluconeogenesis by Perfused Livers of Fed or Fasted Non-Obese and ob/ob Mice.

As shown in Table 1, basal glucose production was similar in livers of both fasted lean and fasted $o b / o b$ mice, although livers of $o b / o b$ mice were not completely depleted of glycogen even after a $24 \mathrm{~h}$ fast (liver glycogen content: fasted lean mice $=$ less than $1 \mathrm{mg} / \mathrm{g}$ liver, fasted $o b / o b$ mice between $1-5 \mathrm{mg} / \mathrm{g}$ liver). The addition of lactate to the perfusate resulted in an augmentation in net glucose production, due to gluconeogenesis, that was similar in livers of both groups of mice (Table 1). Similarly, in fed animals, rates of gluconeogenesis were the same in lean and $o b / o b$ mice when labelled glucose production from labelled pyruvate was measured (Table 2). 


\section{Lipogenesis and Triglyceride Secretion by Perfused Livers of Lean and ob/ob Mice}

As illustrated in Fig. 1, it is obvious that livers of $o b / o b$ mice have an abnormal regulation of lipid metabolism that eventually results in excessive storage of fat within the hepatocytes. Thus, liver parenchymal cells of $o b / o b$ mice contain numerous lipid droplets of varying size, whereas only a few lipid droplets can be observed in the hepatocytes of lean controls. This morphological observation is consonant with the finding of a much higher total lipid and triglyceride content in livers of $o b / o b$ than in those of control mice (total lipids $32 \pm 2(n=13) \mathrm{mg} / \mathrm{g}$ for controls, $243 \pm 12(\mathrm{n}=$ 12) for $o b / o b$; triglycerides $15 \pm 2$ for controls, $151 \pm 12$ for $o b / o b)$.

Table 1. Gluconeogenesis in perfused livers of fasted lean and $o b / o b$ mice

\begin{tabular}{llll}
\hline & \multicolumn{2}{c}{$\begin{array}{l}\text { Glucose production } \\
(\mu \text { moles/g/h) }\end{array}$} & $\begin{array}{l}\text { Glucose } \\
\text { production } \\
\text { Animals }\end{array}$ \\
\cline { 2 - 4 } & $\begin{array}{l}\text { No substrate } \\
\text { in perfusate }\end{array}$ & $\begin{array}{l}\text { in perfusate } \\
(\mu \text { moles/g/h })\end{array}$ \\
& $(\mathrm{A})$ & $(\mathrm{B})$ & $(\mathrm{B}-\mathrm{A})$ \\
\hline Lean & $14 \pm 7$ & $62 \pm 8$ & 48 \\
ob/ob & $8 \pm 6$ & $55 \pm 5$ & $47^{\mathrm{a}}$ \\
\hline
\end{tabular}

Livers from $24 \mathrm{~h}$ fasted mice were perfused with recirculating medium. Lactate was added to the reservoir at the beginning of the experiment. Each value is the mean of 5 experiments $\pm \mathrm{S} . \mathrm{E}$.

a Difference from control livers : NS.

Table 2. Pyruvate metabolism by perfused livers of fed lean and ob/ob mice

\begin{tabular}{llr}
\hline & Lean & ob/ob \\
\hline Perfusate: & \multicolumn{2}{l}{$(\mu$ moles/g/h $)$} \\
Pyruvate uptake & $120 \pm 2$ & $112 \pm 4$ \\
Lactate production & $49 \pm 3$ & $31 \pm 5$ \\
${ }^{14} \mathrm{C}$ glucose production & $16 \pm 1$ & $19 \pm 2$ \\
${ }^{14} \mathrm{C}$ pyruvate oxidation to $\mathrm{CO}_{2}$ & $12 \pm 1.3$ & $6 \pm 1.2^{\mathrm{a}}$ \\
Liver: & $(\mu$ moles/g/h) \\
14C pyruvate incorporation & $0.96 \pm 0.23$ & $2.47 \pm 0.38^{\mathrm{b}}$ \\
into fatty acid & & \\
\hline
\end{tabular}

Livers from mice were perfused with non-recirculating medium containing $2 \mathrm{mM}$ U-14 $\mathrm{C}$ pyruvate $(25 \mu \mathrm{Ci} / \mathrm{mmole})$. Each value is the mean of 3 experiments $\pm S . E$.

a $p<0.05$.

$\mathrm{b} p<0.05$.

In an attempt to delineate the anomalies of lipid metabolism prevailing in the liver of $o b / o b$ mice, a first series of experiments was carried out using $\mathrm{U}_{-}{ }^{14} \mathrm{C}$ pyruvate as a substrate (Table 2). Interference by other labelled substrates (e.g. glucose), derived from labelled pyruvate, was avoided by using a "flow through" technique in which the perfusion medium was collected after a single passage through the liver.

The uptake of pyruvate and the production of lactate were similar in livers of both lean and $o b / o b$ mice. Hepatic ${ }^{14} \mathrm{C}-p y r u v a t e$ oxidation to $\mathrm{CO}_{2}$ was lower in livers of $o b / o b$ mice than in non-obese controls, but the incorporation of pyruvate carbon into triglyceride fatty acids was 2.5 fold higher in livers of $o b / o b$ mice than in those of lean controls. The relative incorporation of pyruvate carbon into liver triglyceride fatty acids, triglyceride glycerol and the non-saponifiable fraction is shown in Fig. 2. The incorporation of pyruvate carbon into triglyceride fatty acids was considerably higher in livers of $o b / o b$ than in those of nonobese controls, in which most of the pyruvate carbon was incorporated into the triglyceride glycerol moiety. As liver glycogen stores are different [18], and as activities of glycolytic and gluconeogenic enzymes differ in livers of lean and $o b / o b$ mice [19], it was thought that specific activity of pyruvate within the liver was also likely to differ markedly, thus making the interpretation of results difficult. To overcome this potential problem, the next series of experiments measured the incorporation into lipids of tritium from ${ }^{3} \mathrm{H}_{2} \mathrm{O}$, according to a method previously reported [20, 21]. The specific activity of tritiated water in perfusate and tissues being constant and identical in both groups, experiments could be performed with recirculating medium. This permitted the simultaneous measurement of total lipogenesis (i.e. ${ }^{3} \mathrm{H}$ incorporation into triglyceride fatty acids of liver + perfusate) and of newly synthesized triglyceride release (i.e. ${ }^{3} \mathrm{H}$ incorporation into perfusate triglyceride fatty acids). Using this procedure it was observed (Table 3 ) that basal lipogenesis (i.e. no added substrate) was much higher in livers of $o b / o b$ than in those of control mice. The addition of various substrates, such as glucose, fructose, pyruvate or acetate, resulted in increases in lipogenic rates that were always greater in $o b / o b$ mice. In a similar fashion, secretion of newly synthesized triglycerides, both in the presence and absence of lipogenic substrates, was greater in livers of $o b / o b$ mice. However, the relative proportion of newly synthesized triglycerides was about the same in both groups (Table 3 ). When total secretion of triglycerides (i.e. unlabelled + labelled) was measured, it was observed (Fig. 3) that perfused livers of lean mice secreted triglycerides at a low rate in the absence of fatty acids in the medium, and that the secretion was greatly stimulated by the addition of albumin-bound oleate, as previously reported for perfused rat livers [22]. In contrast, basal secretion of triglycerides by livers of $o b / a b$ mice was considerably higher than that of the controls, but was not further stimulated by the addition of oleate to the perfusion medium (Fig. 3). In other experiments, it was observed (Table 4) that, although the uptake of oleate was similar in livers of lean and obese mice, oleate oxidation to ketone bodies was considerably smaller in the livers of $o b / o b$ mice. In addition, the presence of oleate resulted in an inhibition of lipogenesis from glucose only in livers of lean mice. 
Lipogenesis and Triglyceride Secretion by Perfused Livers of Lean and oblob Mice Treated with Streptozotocin

As $o b / o b$ mice are continuously exposed to high plasma insulin. levels and, as insulin has been shown to stimulate liver lipogenesis [23, 24], it seemed possible that insulin might play a role in the anomalies of lipid metabolism observed in livers of $o b / o b$ mice. To test such a possibility, $o b / o b$ mice were treated with strepto- zotocin to make them relatively insulin-deficient. Their livers were perfused 6-10 days later and compared with livers of untreated $o b / o b$ mice. The results of these experiments are illustrated in Table 5 . As can be seen, the incorporation of tritium into total triglyceride fatty acids was markedly reduced in livers from the streptozotocin-treated, obese mice. Similarly, newly synthesized triglyceride secretion, as well as total hepatic lipid content, was reduced in livers from

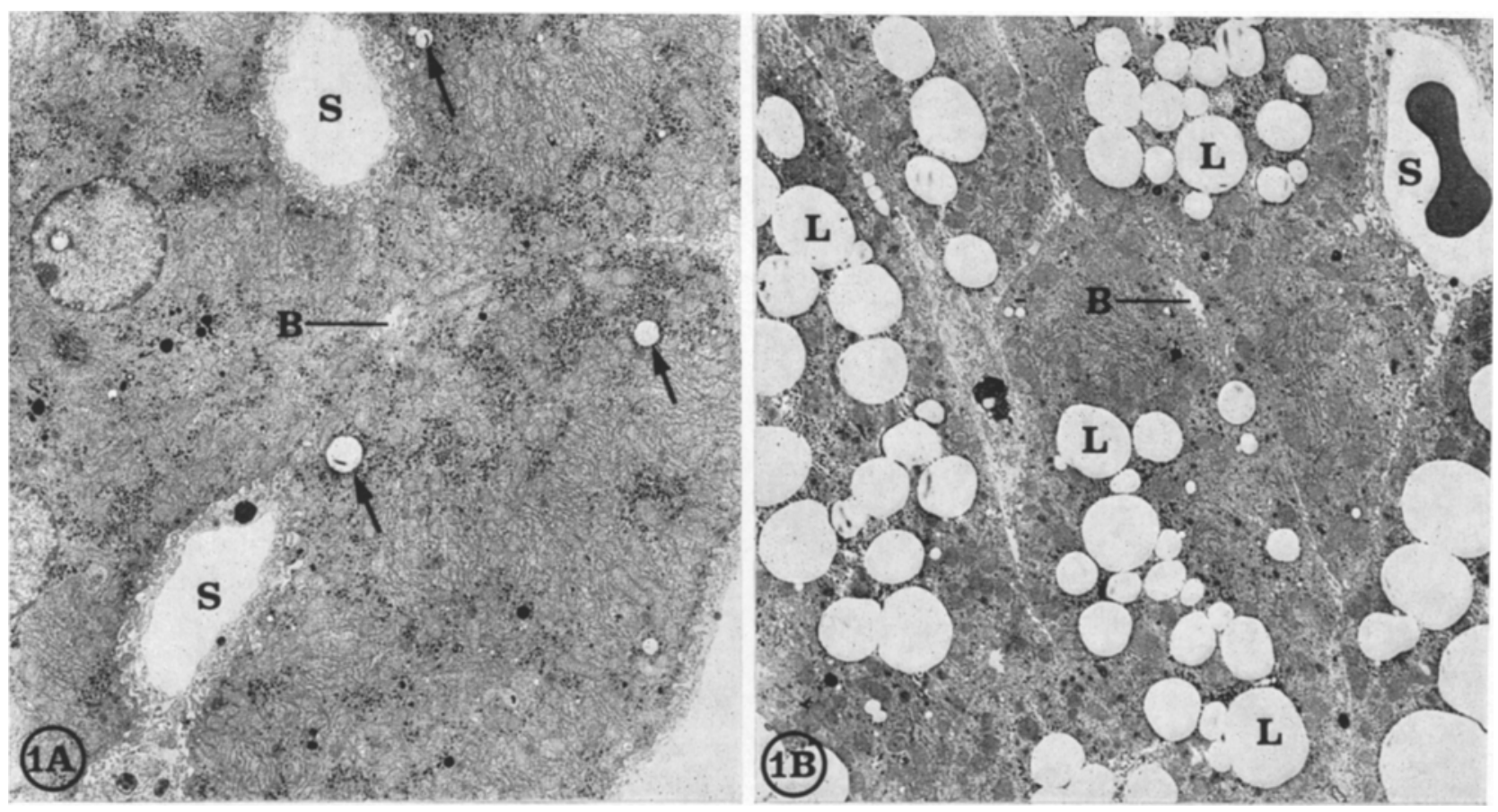

Fig. 1A. Liver from a lean mouse. The hepatocytes contain only a few lipid droplets (arrows). Fig. 1B. Liver from an $o b / o b$ mouse. Numerous lipid droplets (L) are seen within the hepatocytes. B: Bile canaliculus; S: Sinusoid. Fig'. $1 \mathrm{~A}$ and $\mathrm{B} \times 2000$

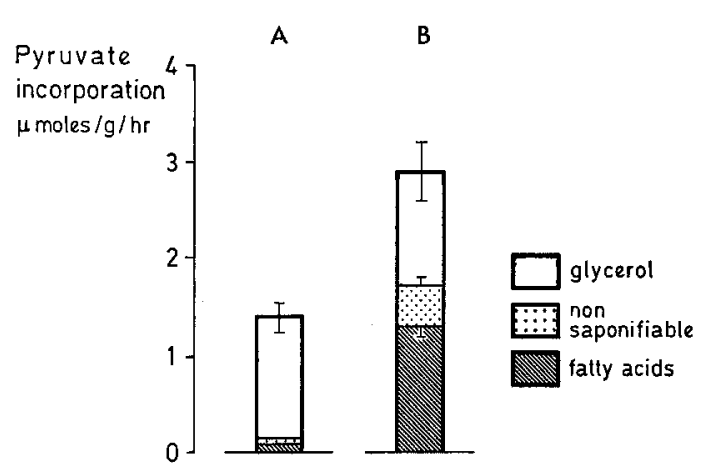

Fig. 2. Lipogenesis from pyruvate in perfused livers of fed lean and $o b / o b$ mice. Livers were perfused with nonrecirculating medium containing $2 \mathrm{mM}$ U-14 $\mathrm{C}$ pyruvate. Glycerol $=$ triglyceride glycerol. Fatty acids $=$ triglyceride fatty acids. Radioactivity in the triglyceride fatty acid and the non-saponifiable fractions, as well as in total lipids, has been measured as described in Materials and Methods; triglyceride glycerol was then calculated from total lipids. Each bar represents the mean of 5 experiments \pm S.E. A: lean mice. B: $o b / o b$ mice streptozotocin-treated $o b / o b$ mice (Table 5). It should be emphasised that streptozotocin-treatment did not change glucose or urea production in subsequently perfused livers. The anomalies of triglyceride secretion, previously observed in perfused livers of $o b / o b$ mice (Fig. 3), could also be restored towards normal by treatment of these mice with streptozotocin (Fig. 4). Thus, livers from untreated $o b / o b$ mice exhibited a high basal triglyceride secretion, which could not be further stimulated by oleate. In contrast, the secretion of triglyceride by livers of streptozotocin-treated, $o b / o b$ mice was markedly decreased and reached values that were close to those observed in livers of non-obese controls. Furthermore, such livers were now able to respond to the addition of albumin-bound oleate to the perfusate, with a marked increase in triglyceride secretion. Similarly, in the presence of added oleate, ketone body production by livers of untreated obese mice was very low, but attained, following streptozotocintreatment, values that were comparable to those observed in livers of lean controls (Fig. 5). 
Table 3. Incorporation of tritium into triglyceride fatty acids (TGF A) by livers of fed lean and ob/ob mice perfused with tritiated water: effect of various substrates

\begin{tabular}{|c|c|c|c|c|c|c|c|}
\hline \multicolumn{5}{|l|}{ Lean } & \multirow{2}{*}{\multicolumn{3}{|c|}{$\begin{array}{l}\text { Obese } \\
{ }^{3} \mathrm{H} \text { incorporation into: }\end{array}$}} \\
\hline \multirow{2}{*}{$\begin{array}{l}\text { Substrate } \\
\text { added }\end{array}$} & \multirow{2}{*}{$\begin{array}{l}\text { No of } \\
\text { expts. }\end{array}$} & \multicolumn{3}{|c|}{${ }^{3} \mathrm{H}$ incorporation into: } & & & \\
\hline & & $\begin{array}{l}\text { Total TGFAa } \\
\text { (uatom } \mathrm{H} / \mathrm{g} / \mathrm{h} \text { ) }\end{array}$ & Released TGFA $^{\mathrm{b}}$ & $\begin{array}{l}\% \text { TGFA } \\
\text { releasedc }\end{array}$ & $\begin{array}{l}\text { Total TGFAa } \\
(\text { uatom } \mathrm{H} / \mathrm{g} / \mathrm{h})\end{array}$ & Released TGFA & $\begin{array}{l}\% \text { TGFA } \\
\text { released }\end{array}$ \\
\hline 0 & 8 & $38 \pm 5$ & $8 \pm 3$ & 21 & $93 \pm 17$ & $20 \pm 4$ & 22 \\
\hline $\begin{array}{l}\text { Glucose } \\
(11 \mathrm{mM})\end{array}$ & 4. & $103 \pm 13$ & $21 \pm 5$ & 20 & $318 \pm 27$ & $74 \pm 13$ & 23 \\
\hline $\begin{array}{l}\text { Fructose } \\
(2 \mathrm{mM})\end{array}$ & 3 & $92 \pm 20$ & $13 \pm 5$ & 14 & $218 \pm 13$ & $39 \pm 7$ & 18 \\
\hline $\begin{array}{l}\text { Pyruvate } \\
\text { (1 mM) }\end{array}$ & 4 & $78 \pm 14$ & $11 \pm 3$ & 14 & $106 \pm 13$ & $18 \pm 4$ & 17 \\
\hline $\begin{array}{l}\text { Acetate } \\
(10 \mathrm{miM})\end{array}$ & 4 & $347 \pm 53$ & $68 \pm 12$ & 20 & $614 \pm 75$ & $94 \pm 21$ & 15 \\
\hline
\end{tabular}

Livers from fed mice were perfused with recirculating medium containing tritiated water. Substrates were added to the reservoir at the beginning of the experiments. Values are means of $3-8$ experiments $\perp$ S.E. as indicated.

$a=$ Total TGFA = incorporation of tritium into triglyceride fatty acids of liver + perfusate.

$\mathrm{b}=$ Released TGFA = incorporation of tritium into triglyceride fatty acids released into the perfusate = index of release of newly synthesized triglycerides.

$c=$ Percentage of total TGEA that is released.

Table 4. Effect of oleate on ketogenesis and lipogenesis by perfused livers of fed lean and ob/ob mice

\begin{tabular}{|c|c|c|c|c|}
\hline \multirow{3}{*}{ Animals } & \multicolumn{2}{|l|}{ Experiment $\mathrm{A}$} & \multicolumn{2}{|l|}{ Experiment B } \\
\hline & \multirow[t]{2}{*}{$\begin{array}{l}\text { Oleate uptake } \\
(\mu \text { moles } / g / h)\end{array}$} & \multirow[t]{2}{*}{$\begin{array}{l}\text { Ketone body pro- } \\
\text { duction }\end{array}$} & \multicolumn{2}{|c|}{ 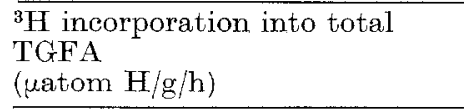 } \\
\hline & & & Without oleate & With oleate \\
\hline $\begin{array}{l}\text { Lean } \\
o b / o b\end{array}$ & $\begin{array}{l}16.9+1.2 \\
14.4 \pm 0.4\end{array}$ & $\begin{array}{r}17.4 \pm 1.9 \\
7.2 \pm 0.3\end{array}$ & $\begin{array}{r}94 \pm 14 \\
197 \pm 26\end{array}$ & $\begin{array}{r}45 \pm 11^{\mathrm{a}} \\
138 \pm 7 \mathrm{~b}\end{array}$ \\
\hline
\end{tabular}

Experiment A: Livers from fed mice were perfused with non-recirculating medium containing $1.2 \mathrm{mM}$ oleate. Ketone body production: acetoacetate $+\beta$ hydroxybutyrate.

Experiment B: Livers from fed mice were perfused with recirculating medium containing tritiated water, $11 \mathrm{mM}$ glucose and $1 \mathrm{mM}$ oleate as indicated. Lipogenesis refers to incorporation of tritium into total (i.e. liver + perfusate) triglyceride fatty acids (TGFA). All values are means of 3 experiments \pm S.E.

$\mathrm{a}=$ Oleate effect, $p<0.05 ;{ }^{\mathrm{b}}=$ Oleate effect, N.S.

Table 5. Effect of streptozotocin diabetes on tritium incorporation into triglyceride fatty acids (TGFA) by livers of fed ob/ob mice perfused with tritiated water

\begin{tabular}{|c|c|c|c|c|c|c|c|}
\hline \multirow{2}{*}{$\begin{array}{l}\text { Streptozotooin } \\
\text { administered } \\
(\mathrm{mg} / \mathrm{kg})\end{array}$} & \multirow{2}{*}{$\begin{array}{l}\text { No of } \\
\text { expts. }\end{array}$} & \multirow{2}{*}{$\begin{array}{l}\Delta \text { body } \\
\text { weight } \\
\text { (g) }\end{array}$} & \multirow{2}{*}{$\begin{array}{l}\text { Plasma } \\
\text { glucose } \\
(\mathrm{mg} \%)\end{array}$} & \multirow{2}{*}{$\begin{array}{l}\text { Plasma IRI } \\
(\mathrm{ng} / \mathrm{ml})\end{array}$} & \multirow{2}{*}{$\begin{array}{l}\text { Liver lipids } \\
(\mathrm{mg} / \mathrm{g})\end{array}$} & \multicolumn{2}{|c|}{${ }^{3} \mathrm{H}$ incorporation into: } \\
\hline & & & & & & $\begin{array}{l}\text { Total TGFAa } \\
\text { ( } \text { katom } \mathrm{H} / \mathrm{g} / \mathrm{h} \text { ) }\end{array}$ & Released TGFA ${ }^{\mathrm{b}}$ \\
\hline \multicolumn{8}{|l|}{ Experiment A } \\
\hline $\begin{array}{r}0 \\
220\end{array}$ & $\begin{array}{l}4 \\
4\end{array}$ & $\begin{array}{l}+6.4 \\
+0.7\end{array}$ & $\begin{array}{l}297 \pm 23 \\
402 \pm 44\end{array}$ & $\begin{array}{l}4.7 \pm 1.2 \\
1.8 \pm 0.3\end{array}$ & $\begin{aligned} 146 & \pm 21 \\
75 & \pm 14\end{aligned}$ & $\begin{array}{r}179 \pm 22 \\
93 \pm 18\end{array}$ & $\begin{array}{l}36 \pm 7 \\
22 \pm 4\end{array}$ \\
\hline \multicolumn{8}{|l|}{ Experiment B } \\
\hline $\begin{array}{r}0 \\
230\end{array}$ & $\begin{array}{l}6 \\
5\end{array}$ & $\begin{array}{l}+3.0 \\
-2.7\end{array}$ & $\begin{array}{l}280 \pm 28 \\
382 \pm 40\end{array}$ & $\begin{array}{l}6.8 \pm 2.2 \\
1.9 \pm 0.3\end{array}$ & $\begin{array}{r}179 \\
67 \pm 16\end{array}$ & $\begin{array}{r}124 \pm 19 \\
19 \pm 6\end{array}$ & $\begin{aligned} 26 & \pm 5 \\
7 & \pm 2\end{aligned}$ \\
\hline
\end{tabular}

$O b / o b$ mice were injected i-p with streptozotocin as indicated. Liver perfusions were carried out 10 (Experiment A) or 6 days (Experiment B) after streptozotocin treatment. $\Delta$ body weight refers to weight changes between day of streptozotocin-treatment and experimental day. Plasma glucose and insulin levels were measured immediately prior to experiments. Livers were perfused with recirculating medium containing tritiated water and $11 \mathrm{mM}$ glucose. a $=$ Total TGFA = incorporation of tritium into triglyceride fatty acids of liver + perfusate. $\mathrm{b}=$ Released TGFA $=$ incorporation of tritium inte triglyceride fatty acids released into the perfusate. Values are means of $4-6$ experiments \pm S.E., as indicated. Due to metabolic variability from one month to another it should be stressed that livers of lean non-treated mice perfused at the same time under the same conditions exhibited a ${ }^{3} \mathrm{H}$ incorporation into total TGFA of $45 \pm 3 \mu$ atom $\mathrm{H} / \mathrm{g} / \mathrm{h}$ (mean of $6 \mathrm{exp} . \pm \mathrm{S}$.E.). 
A

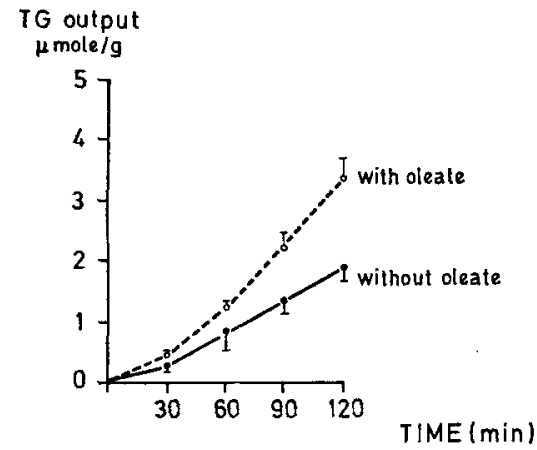

B

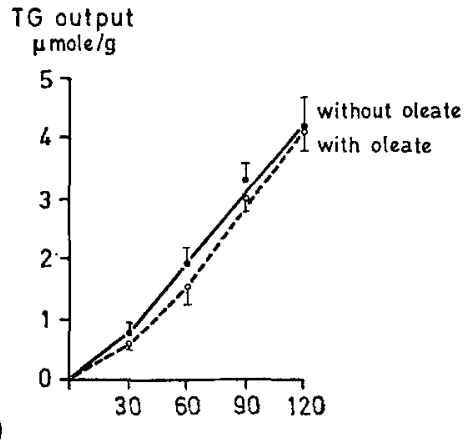

Fig. 3. Secretion of total (unlabelled + labelled) triglycerides by perfused livers of fod lean and ob/ob mice: Effect of oleate. Livers were perfused with recirculating medium containing $11 \mathrm{mM}$ glucose and, when indicated, $2 \mathrm{mM}$ oleate. Each point is the mean of 3 experiments \pm S.E. A: lean mice. B: ob/ob mice

A

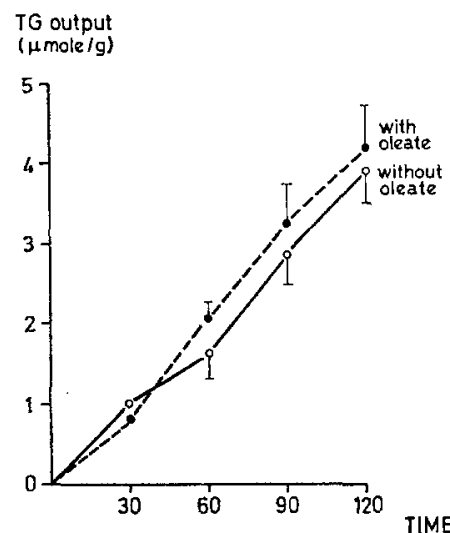

B

TG output

( $\mu$ mole/g)

Fig. 4. Secretion of total (unlabelled + labelled) triglycerides by perfused livers of fed, non-treated and streptozotocintreated $o b / o b$ mice: Effect of oleate. Livers were perfused with recirculating medium containing $11 \mathrm{mM}$ glucose and, when indicated, $2 \mathrm{mM}$ oleate. Streptozotocin-treated $o b / 0 b$ mice received $230 \mathrm{mg} / \mathrm{kg}$ of the compound i-p 6 days prior to experiments. Each point is the mean of $\tilde{5}-6$ experiments \pm S.E. Treated $o b / o b$ mice: with oleate versus without, $p<0.0125$. A: non-treated $o b / o b$ mice. B: streptozotocin-treated ob/ob mice

A

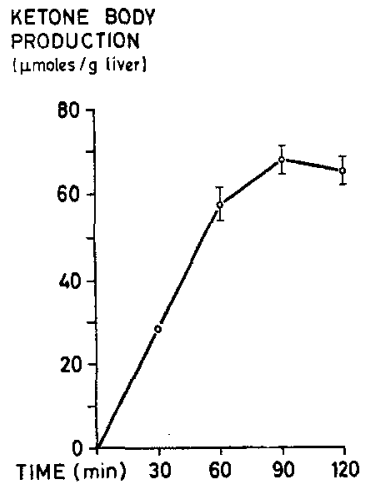

B

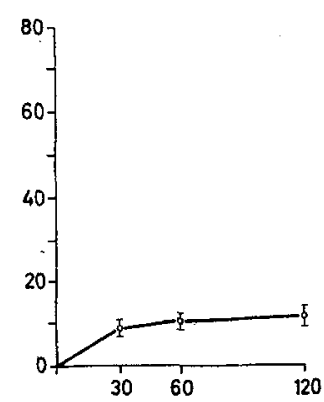

$\mathrm{C}$

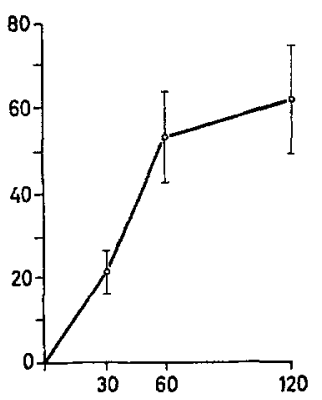

Fig. 5. Ketone body production (acetoacetate $+\beta$-hydroxybutyrate) by perfused livers of fed lean, non-treated and streptozotocin-treated $o b / o b$ mice. Exptl. conditions as described in Fig. 3 except for oleate concentration (1.2 mM) Each point is the mean of 3 experiments \pm S.E. A: lean mice. B: non-treated $o b / o b$ mice. C: streptozotocin-treated ob/ob mice 


\section{Discussion}

The experiments summarized in this study provide the first attempt to investigate lipogenesis and triglyceride secretion in livers of non-obese and $o b / o b$ mice using a perfusion technique.

The experiments carried out with $\mathrm{U}^{14} \mathrm{C}$ pyruvate as substrate (Table 2, Fig. 2) show that liver lipogenesis is greatly increased in livers of $o b / 0 b$ mice. In addition, these experiments indicate that pyruvate carbon incorporation into triglyceride fatty acids is much greater in livers of $o b / o b$ mice than in lean controls. The increased lipogenesis in livers of $o b / o b$ mice was also demonstrated in experiments using ${ }^{3} \mathrm{H}_{2} \mathrm{O}$, in which basal lipogenesis, as well as lipogenesis stimulated by glucose, fructose, pyruvate or acetate, was, on a per gramme liver basis, two or three times higher in livers of $o b / o b$ mice than in controls (Table 3). Furthermore, a close relationship appears to exist between total lipid synthesis and release of newly synthesized triglyceride in livers of both normal and obese mice. Consequently, livers of $o b / o b$ mice release, under all circumstances, more newly formed (i.e. labelled) triglyceride than livers of the non-obese controls. In addition, total (i.e. unlabelled + labelled) triglyceride secretion is also considerably higher in $a b / o b$ mice. Such total triglyceride secretion appears to be maximally stimulated in livers of $o b / o b$ mice, since it cannot be stimulated. further by an exogenous fatty acid, such as oleate. It is interesting that, when $o b / 0 b$ mice become relatively insulin-deficient, following streptozotocin-treatment, hepatie lipogenesis in the presence of glucose, as well as release of newly synthesized triglycerides, are both restored towards normal (Table 5). The very high release of total triglycerides observed in livers of $o b / o b$ mice (Fig. 3, 4) is also greatly reduced following streptozotocin-treatment and, more importantly, triglyceride secretion can, under these conditions, be stimulated by exogenous fatty acids, as in livers of nonobese mice. On the basis of these experiments we propose that the anomalies of lipid metabolism prevailing in livers of $a b / o b$ mice are due, at least in part, to a chronic stimulation of the hepatic parenchyma by insulin, due to the well-documented hyperinsulinaemia of these animals. Although the mode of action of insulin on hepatic carbohydrate and lipid metabolism is still unclear, the concept of a causal role of hyperinsulinism in the lipid disorders of $o b / o b$ mice is in keeping with previous studies carried out on insulin action, using perfused rat livers or rat liver slices. Thus, as recently reviewed by Nikkilä [23] and Lowenstein [24], insulin has been shown to increase acetate incorporation into fatty acids in rat liver slices incubated in vitro. Addition of insulin also resulted in increased lipogenesis from acetate or glucose in perfused livers of normal rats $[23,24]$. Conversely, livers of rats made diabetic with alloxan, or treated with anti-insulin serum, showed an extremely low rate of lipogenesis, which was restored to normal by the administration of insulin
$[23,24]$. It has also been shown that insulin is able to stimulate triglyceride output from perfused rat livers [25], and to increase labelled glucose carbon incorporation into triglycerides released by rat liver slices [26]. Rat liver cells do not have an insulin-sensitive permeability barrier to glucose [27] and it has been proposed that insulin may exert its effect on fatty acid synthesis in this tissue by influencing the activity of glucokinase [28], or other enzymes involved in lipid synthesis [23, 24]. Insulin also appears to decrease hepatic triglyceride lipase, perhaps by lowering tissue levels of cyclic AMP [23]. It is possible that such insulin mediated changes prevail in livers of $o b / o b$ mice and that the chronic presence of insulin results in a continuous stimulation of glucose utilization (with consequent production of reduced coenzymes), a channelling of acetyl-CoAinto long chain fatty acids and a depression of hepatic triglyceride hydrolysis. The association of high triglyceride content, high lipogenesis, high triglyceride secretion and very low ketogenesis observed, in the present study, in livers of $o b / o b$ mice are in agreement with such a view. Also, the lesser inhibitory effect of added oleate on hepatic lipogenesis in $o b /$ $o b$ mice (Table 4) might be related to a decreased fatty acid or fatty acyl-CoA accumulation in livers chronically stimulated by insulin.

In addition, as previously reported [29], these experiments indicate that the capacity for gluconeogenesis from lactate or pyruvate is not altered in perfused livers from fed or fasted $o b / o b$ mice, when compared with that of lean mice.

Acknowledgements. The stimulating comments and suggestions of Dr. R.M. Denton, Dr. M.D. Siperstein and Dr. G.W.G. Sharp are gratefully acknowledged. We are greatly indebted to Mrs. Josette Piroud-Petitjean, Miss Maria Brunsmann, Mrs. Martha Sidler-Ansermet and Miss Olgica Jerotic for their very expert and tireless technical assistance. We are grateful to Dr. A. Gutzeit for performing the insulin immunoassays.

\section{References}

1. Shigeta, Y., Shreeve, W.W.: Fatty acid synthesis from glucose-1- ${ }^{3} \mathrm{H}$ and glucose $-1-{ }^{14} \mathrm{C}$ in obese hyperglycaemic mice. Amer. J. Physiol. 206, 1085-1090 (1964)

2. Bates, M. W., Zomzely, C., Mayer, J. : Fat metabolism in three forms of experimental obesity. IV. Instantaneous rates of lipogenesis in vivo. Amer. J. Physiol. $181,187-190(1955)$

3. Jansen, G.R., Zanetti, M.E., Hutchison, C.F.: Studies on lipogenesis in vivo. Fatty acid and cholesterol synthesis in hyperglycaemic-obese mice. Biochem. J. 102, 870-877 (1967)

4. Winand, J.: Aspects qualitatifs et quantitatifs du métabolisme lipidique de la souris normale et de la souris congénitalement obèse. Bruxelles: Editions Arscia S.A. 1970

5. Bray, G.A., York, D. A. : Genetically transmitted obesity in rodents. Physiol. Rev. 51, 598-646 (1971)

6. Chang, H.C.. Seidman, I., Teebor, G., Lane, M.D. : Liver acetyl CoA carboxylase and fatty acid synthetase: relative activities in the normal state and in 
hereditary obesity. Biochem. biophys. Res. Commun. 28, 682-686 (1967)

7. Kornacker, M.S., Lowenstein, J.M.: Citrate cleavage enzyme in livers of obese and non obese mice. Science 144, 1027-1028 (1964)

8. Assimacopoulos-Jeannet, F., Exton, J.H., Jeanrenaud, B.: Control of gluconeogenesis and glycogenoly. sis in perfused livers of normal mice. Amer. J. Physiol. 225, 25-32 (1973)

9. Chen, R.F.: Removal of fatty acids from serum albumin by charcoal treatment. J. biol. Chem. 242, $173-181(1967)$

10. Le Marchand, Y., Singh. A., Assimacopoulos-Jeannet, F., Orci, L., Rouiller, Ch., Jeanrenaud, B.: A role for the microtubular system in the release of very low density lipoproteins by perfused mouse livers. J. biol. Chem. 248, 6862-6870 (1973)

11. Hohorst, H.J.: Methods of enzymatic analysis, pp. 266-270. (Ed. Bergmeyer, H.U.). Weinheim-New York-London: Verlag Chemie and Academic Press 1963

12. Bücher, T., Czok, R., Lamprecht, W., Latzko, E.: Methods of enzymatic analysis, pp. 253-259. (Ed. Bergmeyer, H. U.). Weinheim-New York-London Verlag Chemie and Academic Press 1963

13. Mellanby, J., Williamson, D.H.: Methoden der Enzymatischen Analyse, pp. 1776-1779. (Ed. Bergmeyer, H.U.). Ed. 2. Weinheim: Verlag Chemie 1970

14. Williamson, D.H., Mellanby, J.: Methoden der Enzy * matischen Analyse, pp. 1772-1775. (Ed. Bergmeyer, H.U.). Ed. 2. Weinheim: Verlag Chemie 1970

15. Ho, R.J.: Radiochemical assay of long chain fatty acids using ${ }^{63} \mathrm{Ni}$ as tracer. Analyt. Biochem. 36, 105$113(1970)$

16. Heindel, J.J., Cushman, S.W., Jeanrenaud, B.: Cell associated fatty acid levels and energy-requiring processes in mouse adipocytes. Amer. J. Physiol. 224, $16-24(1974)$

17. Folch, J., Lees, M., Sloane-Stanley, G.H.: A simple method for the isolation and purification of total lipids from animal tissues. J. biol. Chem. 226, $497-$ $509(1957)$

18. Abraham, R.R., Dade, E., Elliott, J., Herns, D.A.: Hormonal control of intermediary metabolism in obese hyperglycemic mice. II. Levels of plasma free fatty acid and immunoreactive insulin and liver glycogen. Diabetes 20, 535-541 (1971)

19. Seidman, I., Horland, A.A., Teebor, G. W.: Glycolytic and gluconeogenic enzyme activities in the hereditary obese-hyperglycemic syndrome and in acquired obesity. Diabetologia 6, 313-316 (1970)
20. Jungas, R.L.: Fatty acid synthesis in adipose tissue incubated in tritiated water. Biochemistry 7, 37083717 (1968)

21. Brunengraber, H., Boutry, M., Lowenstein, J.M.: Fatty acid and 3 - $\beta$-hydroxysterol synthesis in the perfused rat liver. J. biol. Chem. 248, 2656-2669 (1973)

22. Kohout, M., Kohoutova, B., Heimberg, M.: The effect of chain length and degree of unsaturation of the fatty acid substrate on the output of triglycerides by the liver. Biochim. biophys. Acta (Amst.) 210, 177$179(1970)$

23. Nikkilä, E. A. : Control of plasma and liver triglyceride kinetics by carbohydrate metabolism and insulin. Advances Lipid Res. 7, 63-134 (1969)

24. Lowenstein, J.M.: Is insulin involved in regulating the rate of fatty acid synthesis? In: Handbook of Physiology. Section 7: Endocrinology. Vol. 1. Endocrine pancreas, pp. 415-424. (Eds. Greep, R.O., Astwood, E.B.). Amer. Physiol. Soc., Washington D.C. 1972

25. Topping, D. L., Mayes, P.A.: The immediate effects of insulin and fructose on the metabolism of the perfused liver. Changes in lipoprotein secretion, fatty acid oxidation and esterification, lipogenesis and carbohydrate metabolism. Biochem. J. 126, 295-311 (1972)

26. Letarte, J., Fraser, T.R. : Stimulation by insulin of the incorporation of $\mathrm{U}^{14} \mathrm{C}$-glucose into lipids released by the liver. Diabetologia 5, 358-359 (1969)

27. Hetenyi, G., Norwich, K.H., Studney, D.R., Hall, J. D. : The exchange of glucose across the liver cell membrane. Can. J. Physiol. Pharmacol. 47, 361-367 (1969)

28. Takeda, Y., Inoue, H., Honjo, K., Tanioka, H., Daikuhara, Y.: Dietary response of various key enzymes related to glucose metabolism in normal and diabetic rat liver. Biochim. biophys. Acta (Amst.) 136, 214$222(1967)$

29. Elliott, J., Hems, D.A., Beloff-Chain, A.: Carbohydrate metabolism of the isolated perfused liver of normal and genetically obese-hyperglycaemic (ob/ob) mice. Biochem. J. 125, $773-780$ (1971)

Prof. B. Jeanrenaud

Laboratoires de Recherches Médicales

Université de Genève

Avenue de la Roseraie 64

CH-1211 Genève 4

Switzerland

Responsible for the text: Prof. Dr. W. CReutzfeudr, Med. Universitätsklinik, Humboldtallee 1, D-34 Göttingen/F. R. G. Prof. Dr. K. Scröfrita, Zentrum der Inneren Medizin, Theodor-Stern-Kai 7, D-6 Frankfurt 70/F. R. G. Responsible for advertisements: L. Sikger G. Martix, D-1000 Berlin 15, Kurfürstendamm 237. Springer-Verlag, Berlin, Heidelberg, New York.

Printed in Germany by Druckerei Georg Appl, Wemding/Schwaben.

Copyright (C) by Springer-Verlag Berlin. Heidelberg 1974 